\title{
StepTogether - a possible solution for teaching Hungarian as a target language to migrant children
}

\author{
ÉDUA ROSTÁS, JUDIT KECSKÉS \\ University of Miskolc
}

\begin{abstract}
This paper introduces the StepTogether programme, which is one of the practices for preventing early school leaving in Hungary. The main goal of the programme is to improve the language competence of migrant pupils and thereby to decrease school dropout rates and support the pupils in their transition from primary to secondary school. The programme develops CLIL aids for migrant children attending primary school in the 3 rd-8th grades. The aim of the developers was to support teachers in integrating children with non-native competence in Hungarian (proficiency level A1-B2) into traditional classroom activities. The StepTogether concept helps children develop their language skills while they are dealing with the same subject topics as their dominant-language classmates. The structure of these teaching tools allows all teachers to contribute to the children's language development process and helps create an open intercultural classroom climate. Furthermore, integrating the heritage cultures of the pupils into the classroom work helps involve migrant parents as well.
\end{abstract}

Keywords: Content Language Integrated Learning; NyIT; early school leaving; preventive practice; CEFR resources; spiral grammar 


\section{Defining the keywords: issues and aims}

In the Education and Training in Europe 2020 strategy, Hungary is listed among the countries (Belgium, Bulgaria, Czech Republic, Denmark, Spain, France, Latvia, Portugal, Romania, Slovenia, Slovakia, Finland, the United Kingdom) where programmes to prevent early school leaving of disadvantaged pupils have been implemented. These pupils, often with a migrant or Roma background, often also suffer from learning difficulties and achieve poorly. The preventive measures in this area focus on language training for migrant children (European Commission/ EACEA/Eurydice 2013: 6). The StepTogether programme is one of these prevention practices in Hungary. The main aim of the programme is to develop migrant students' Hungarian language competencies within the public education system so that they can be integrated into teaching and proceed according to the school curriculum together with their classmates.

The StepTogether programme is a series of projects started in 2010, developed at the Institute of Hungarian Linguistics and Literary Studies at the University of Miskolc. The authors are linguists and pedagogical advisors of the University of Miskolc and the Eötvös Loránd University Faculty of Education and Psychology. Thus far, five main projects have been implemented. These projects were based on our teaching tools and conducted with migrant students and their teachers in six institutions (3 English-Hungarian bilingual schools, 1 Chinese-Hungarian bilingual school, 1 monolingual Hungarian school, 1 monolingual Hungarian school with a multicultural teaching programme) in Budapest.

The programme reflects the fact that the Hungarian public education system faces different challenges in the education of migrants than other European Union countries with a large migrant population. Figure 1 shows these problems from the point of view of the four participants of the learning-teaching process. 


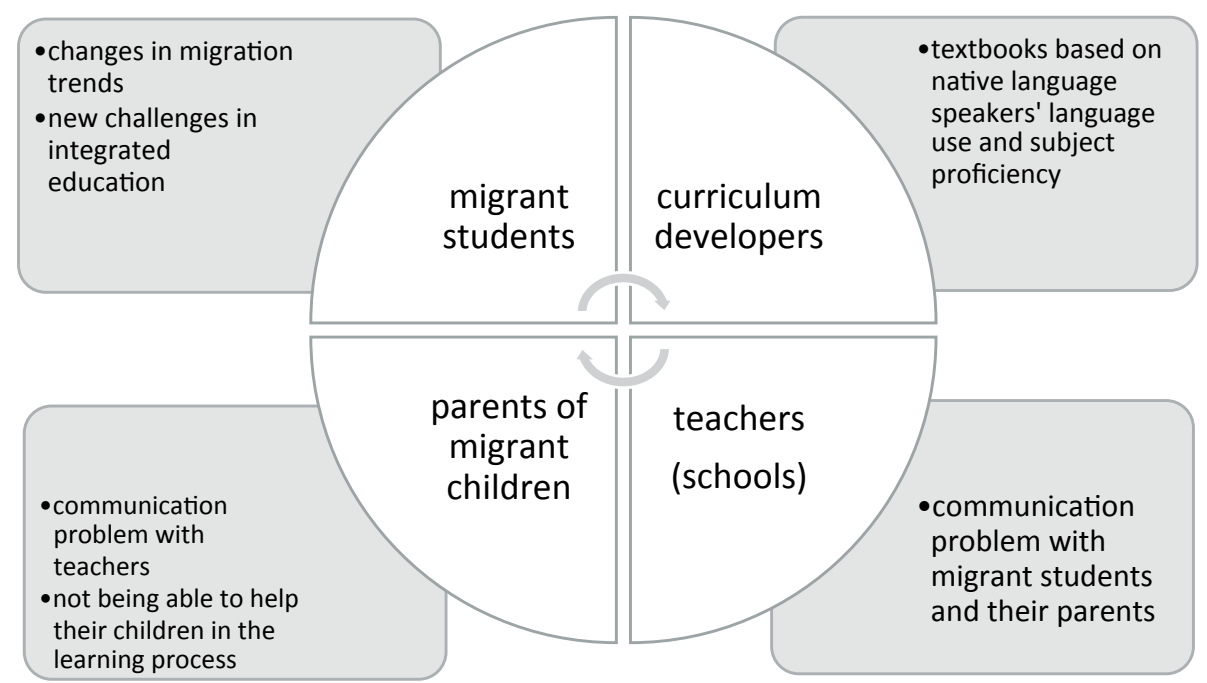

FIGURE 1. The four main participants of Hungarian public education

\subsection{Migrant children}

Migrant children are integrated into public education according to their age, regardless of their language competencies. By parental request, the child may attend a class that does not match his/her age. Beyond the challenge to date - to determine whether the lack of language competencies or an inappropriate age-group environment will cause less frustration for the child in the teaching-learning process - changes in migration trends have posed new challenges to all participants of Hungarian public education.

The waves of immigration in the late 20th and early 21 st century displayed considerable differences in terms of countries of origin. Late 20th century immigration was principally characterised by ethnic migration, i.e. the immigration of ethnic Hungarians from the neighbouring countries (Gödri 2013: 263-265). In the 1980s, migrants and those applying for Hungarian citizenship predominantly came from Romania, Ukraine, Yugoslavia and its successor states, and in small numbers from Slovakia, and $90 \%$ of them were Hungarian-speaking or ethnic Hungarians. In the next decade the Yugoslav wars increased the number of refugees arriving 
from Yugoslavia, while the need for family reunification encouraged migration from the neighbouring countries. At the beginning of the 21 st century, however, the harmonisation of migration laws in the EU, substantial changes in the process of naturalisation (in 2011 and 2013), and the neighbouring countries joining the EU one by one had the joint effect of decreasing immigration from the neighbouring countries (Gödri 2013: 267; Tóth 2013: 248; Wetzel 2011: 66-70).

In the meantime, the composition of the immigrant groups in terms of legal statuses (migrant, refugee, asylum seeker, family reunification, statelessness) has changed. According to the statistics of the Office of Immigration and Nationality (Kiadványfüzet 2014-2015), the number of those applying for asylum has risen sharply, from 42,777 people in 2014 to 177,135 registered asylum seekers in 2015. From the aspect of education, however, the internal structural changes are much more crucial: the number of immigrants from outside Europe is increasing, and in 2015 it was $83.4 \%$ of the total number of asylum seekers (the remaining $16.6 \%$ came from European countries outside the EU).

Until recently, most of the immigrants who came into contact with teachers had no problems with the language which would considerably hinder their progress in education. Members of the Hungarian diaspora, speaking a Hungarian dialect, had no difficulties with the Hungarian grammar. Their problems, if any, pertained to the school-related vocabulary in Standard Hungarian and were easily resolved in the Hungarian educational environment. Consequently, migrants from the neighbouring countries were less likely to leave school prematurely. But most of the migrants in the new wave have deficiencies in literacy and language skills, and not only in the vocabulary: they may lack all basic grammatical knowledge of Hungarian. Therefore, in the past decade a great number of teachers have come into contact with migrants who, due to their language difficulties, may be prone to leave school prematurely. For this reason, a programme had to be developed to improve the language competencies of migrant pupils and thereby decrease early school leaving and aid the pupils' transition from primary to secondary school. 


\subsection{Curriculum developers}

Why are migrant students threatened by early school leaving if there is a separate L2 Hungarian curriculum and Hungarian as a Second Language $(\mathrm{HSL})^{1}$ lessons are provided? Although they are fluent speakers in everyday situations, they have serious deficiencies in their academic language proficiency. The HSL curriculum primarily focuses on traditional grammar teaching and communication competence; the topics in communication are typical of language learning (such as family, travelling, weather etc.) Nevertheless, both migrant students and their teachers experience the learning/teaching of specific subjects as a challenge.

The competences, content and terminology of each specific subject which students in public education should acquire are determined by the National Core Curriculum (NCC; Nat 2012) and the frame curricula. The curriculum and textbook tasks are designed for Hungarian native speakers with a European cultural background. Only in bilingual schools can different teaching tools be used in language classes. However, the languages in Hungarian bilingual schools are predominantly English, German, or Italian (alongside Hungarian), and migrant children usually do not speak these languages either.

Therefore, the aim of the developers of the StepTogether Programme is to create teaching tools for various specific subjects (mathematics, (life) science, history, Hungarian studies, Hungarian language and literature) and for competence development in vocational guidance. These materials conform to NCC and the frame curricula. Their working language is Hungarian but they are not designed for native speakers. The teaching tools can be used in any type of school and together with any textbook series, also in heterogeneous classrooms. The books are centred on the same topics as traditional textbooks but each unit is

\footnotetext{
1 We chose to use the term Hungarian as a Second Language (HSL) in this paper. Note, however, that in Hungarian research and policy, also in the National Core Curriculum, the term magyar mint idegen nyelv ('Hungarian as a foreign language') is used.
} 
complemented by tasks at CEFR proficiency levels from A1 to B1/B2. Children with different levels of knowledge in Hungarian can thus be involved in the process of integrated learning, and pupils whose level of proficiency in Hungarian changes during the schoolyear need not change their textbooks or groups/classes. The programme is based on the idea that elaborated language code and competence will support language learning at a higher level. Accordingly, each thematic unit contains tasks which serve to develop the students' linguistic and intercultural competences. We also bank upon pupils' strategies to learn from one another. Apart from tasks involving pair work or group work, individual tasks can also enable connection and thus improve the students' skills in initiating and maintaining communication.

\subsection{Teachers and schools}

As the classes are often large (usually 27-32 pupils) and mainly consist of Hungarian native speakers, integrating migrant pupils with diverse cultural backgrounds and varying language skills into the classroom work is a major challenge for teachers. Most schools do not have the opportunity to hire a pedagogical assistant, and the groups of migrant pupils are too small and heterogeneous for separate HSL learning groups for different CEFR levels (for a comparable situation in Finland, see Honko 2014: 109). A further problem derives from the fact that there is no lingua franca that would enable communication between older-generation teachers and migrant students. Furthermore, schools primarily hire teachers with qualifications in two general subjects instead of teachers specializing in HSL (Schmidt 2014: 30). As a rule, only HSL and foreignlanguage teachers have received multicultural classroom training. Thus, most teachers of science subjects are not prepared for multicultural and linguistically heterogeneous learning groups.

Therefore, the aim of the StepTogether programme was to provide methodological help for teachers working with migrant pupils. The Grammar Matrix was prepared primarily for teachers who do not teach 
HSL. It introduces the grammar used in the teaching tools at different CEFR levels. The Lexical Matrix was designed with the same method and includes the vocabulary of each subject, classified by the levels A1B1/Other. The Methodological Guidance facilitates the understanding of the methods used in the program and the use of teaching aids. Besides the teaching tools prepared for pupils, for teachers we made assessment tools for measuring attitudes and language competencies, to help them individually assess and follow the development of the pupils' Hungarian language skills. For practitioners we offered further training, while for future teachers the methodology of the programme is taught at university seminars.

\subsection{Immigrant parents}

The main problem of migrant parents choosing public education is the communication gap between them and the teachers/the school. The gap is frequently bridged by the children acting as interpreters or brokers (Trickett \& Jones 2007; Várhalmi 2013: 119; Rostás 2015). In this situation, the parents cannot support their children in learning, and often they do not have an adequate knowledge of the Hungarian system of education and its requirements. Due to the lack of available surveys, we do not even have data about immigrant parents' attitudes towards HSL teaching.

The programme thus aimed to aid in the communication between parents, the school, and teachers. For this purpose, various methods were included in the teaching tools. First, we prepared vocabulary flashcards which may be used for a card game. This way, the vocabulary of school life becomes more accessible for parents as well, so they can help their children in learning or learn together with them. Our vocational guidance flashcards introduce various vocations, their tools and linguistic gender markers ${ }^{2}$, which offer the whole family the opportunity to get

\footnotetext{
2 Mainly the -nö suffix after the root is used to mark female gender in Hungarian grammar. However sometimes different lexical elements are used for vocation titles
} 
to know the Hungarian system of education and labour market. Second, besides flashcards, certain tasks in the teaching tools also target the parents: the teaching tools for History and Hungarian Studies, for example, include tasks which contain the knowledge necessary for a naturalisation application. Other tasks are designed in a way that the parents and the children are required to do a school task together. Finally, we initiated research to assess the changes of identity with different migrant generations (Kecskés \& Kovács 2015).

\section{The steps of the programme}

Our first project, StepTogether I - Migrant Children in School provided teaching tools for migrant pupils in the 5th and 6th grade and their teachers in Hungarian language and literature, mathematics and life sciences. The reason why we started our work with the upper grades and not with the first years of primary school is that the number of subjects starts to grow in the 5th grade, the terminology expands and the pace of teaching increases, which will lead to an almost irremediable disadvantage for migrant students. Also according to Schmidt's (2014: 27) study on the linguistic skills of migrant pupils entering the Hungarian education system, based on Baker's (2011) criteria of bilingualism, those attending grades 5-8 are most likely to fall behind.

The pilot period of our programme involved three schools - one monolingual Hungarian primary school, one English-Hungarian bilingual primary school and one secondary technical school - and altogether 7 teacher participants and 20 students from Bolivia, China, Mongolia, Taiwan, Turkey, Ukraine and Vietnam. From the start, we put an emphasis on involving university students, so five students of Hungarian philology at the University of Miskolc also participated in the project - some of them became collaborators or authors in the later projects.

to show gender preferences. For example, the job called ápoló/növér 'nurse' has two lexical forms: ápoló is the male and növér is the female title of the job. We display both forms and mark the preferred gender of the job title. 
StepTogether II aimed at improving the language skills of 7th- and 8th-graders in connection with the teaching of Hungarian language and literature, mathematics and biology. Besides preparing language teaching tools for upper grades, we also created a new element in the project: the Competence-based Matrix of Language Learning Task Types. This task book was designed for teachers and authors who wish to adapt the tasks to other subjects. Furthermore, we had another partner institution to work with: a bilingual school which did not offer HSL classes.

In 2011 the programme won the European Language Label award, and the evaluation highlights that "the teaching tools facilitate the education of migrant children in Hungary in schools which do not have an intercultural pedagogical program. One of the most positive aspects is that the applicant pays special attention to the various subjects when preparing tools for language teaching". Perhaps it was also owing to this award that we started our third project with six partner schools.

In StepTogether III our focus shifted to lower grades in primary school. We designed teaching tools for 3rd- and 4th-grade Hungarian language and literature, mathematics and environmental studies. Having noticed communication problems among the school, parents and pupils, we added vocabulary flashcards to our teaching tools. Offering a playful way of acquiring the Hungarian language, these flashcards featured not only terminology for these subjects but also groups of words that would aid communication between the parents and the school, including documents (e.g. school report, ID, visa, medical certificate), events in the life of the school (e.g. ceremonies and celebrations, public holidays, parents' meetings) and objects (desk, gym suit, towel etc.).

The aim of StepTogether IV - History and Hungarian Heritage for migrant children was to broaden the structure of subjects we had worked on, so we prepared teaching tools for history from the 3rd to the 8th grade, and two sets of tools for Hungarian Studies. These two subjects offered us the opportunity to facilitate migrant pupils' preparation for the Hungarian citizenship test by using special icons (national flag label) to mark the tasks which are also test items. Based on the 
experience gained from the previous projects, we believed it was time to transfer our knowledge to our university students as well, so as a new element of the project we started the "Linguistic and Cultural Diversity in the School" seminar for them.

Our latest, fifth project, StepTogether V - Career-orientation for migrant youth related to a timely issue in educational policies: vocational guidance. The content base of our teaching tools was provided by material from the National Core Curriculum (Nat 2012), as well as from international specialised literature analysing the transition from the world of education to that of work (Tschibozo 2013: 3-18; Gothard et al. 2001: 93-116, 133-138). Accordingly, the syllabus of vocational guidance consists of Self-knowledge and Career Planning, Communication in the Labour Market and Professions and Trades I-III. These tools are also complemented by a set of vocabulary flashcards for migrant children and their parents. At the same time, seminars were offered not only for university students but practitioners and head teachers as well.

A total of 67 teachers, 228 migrant children and 48 Hungarian university students have taken part in our projects thus far. Our migrant projects were funded by the European Integration Fund, and we were also simultaneously working in other projects connected to a sub-field or branch, for example we investigated the usability of the teaching tools for teaching Roma and disadvantaged children with learning difficulties. The first of these Roma projects was in 2012, based on our previous StepTogether projects and Zita Réger's sociolinguistic studies (Réger 1995; 2002). A developmental course was organised for Roma and disadvantaged children to explore connections between their language usage and learning difficulties and also to prevent their early school leaving. The course focused on the subject fields of mathematics, geography, and Hungarian grammar. 


\section{In focus}

Methodologically, our project is based on the models of European Content and Language Integrated Learning (CLIL) and American-Canadian Content Based Instruction (CBI). These two approaches are basically dual-focused teaching forms. The main difference between them is that CBI focuses more on content than on language, with content providing the basis for language teaching as well, whereas in CLIL language and content overlap and jointly form the basis for this approach. According to CLIL, transmitting non-linguistic knowledge does not take place in the language of the host country, but with and through it (Coyle et al. 2010: 36). We were also influenced by Equity Pedagogy, the Complex Instruction Programme (CIP) and its Hungarian adaptation the KIP (Cohen 1991; Cohen \& Lotan 2004; K. Nagy 2012; Bunch et al. 2015); these influences are most clearly present in the fifth project's design of cooperative tasks. We agree with the idea of the CIP that the more the students talk and work together, the more they learn. However, students who are socially isolated and less confident in their academic skills often fail to participate and therefore learn less than their capacities would allow (Cohen \& Lotan 1997). Therefore, as other countries adapted the CLIL model for their own specific social-educational problems (LAK in Estonia, ITALIC in Italy), we created NyIT, a uniquely blended Hungarian version of CLIL. NyIT is a Hungarian acronym: $\mathrm{Ny}$ is for nyelv 'language', I is for Integration, and T is for tartalom 'content', while the verb nyit means "to open" in Hungarian. NyIT is a trial-focused educational approach. The focus is heavily on language, but the approach is not grammar-focused in the traditional way. The grammar appearing in the units of the teaching material is not vertically built but organised in a spiral manner (Figure 2.). 

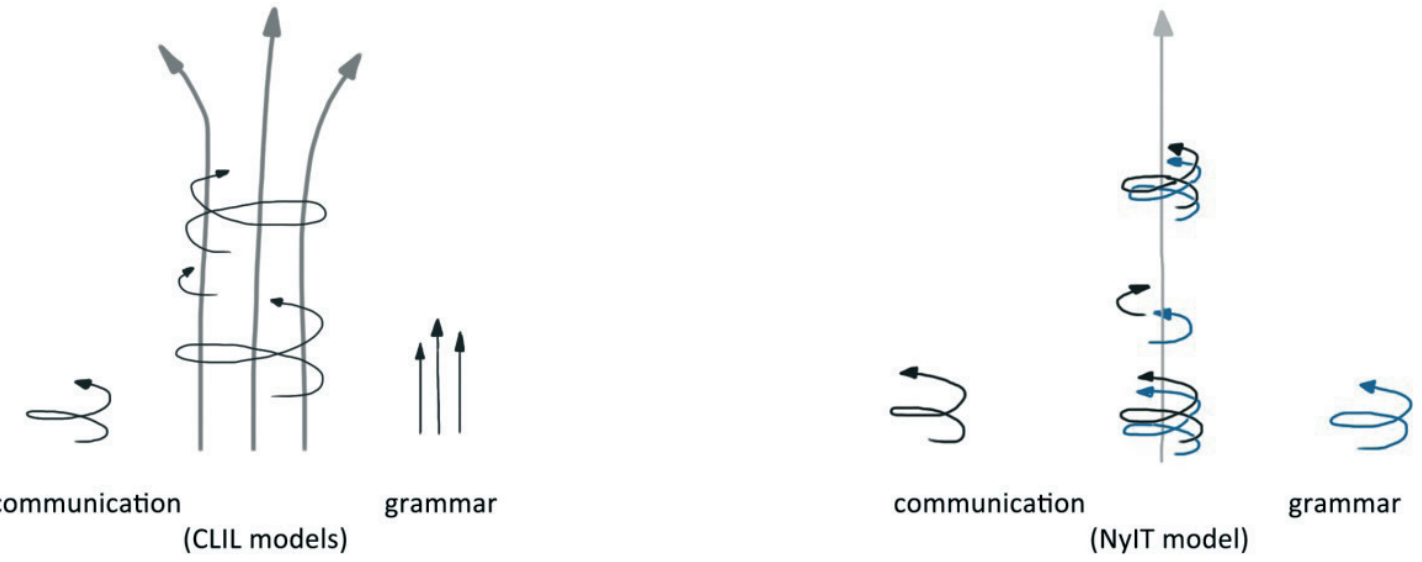

FIGURE 2. The language teaching models of CLIL and NyIT

Taking into account the fact that migrant children arrive in the classroom at any time or period during the school-year, basic grammatical phenomena are recurring in the units. While in traditional language teaching methods a unit is built around one single grammatical element (e.g. the accusative case), in our tools the content and the communication situation determines the grammatical phenomena that are to be taught. For this reason, tasks do not focus on one specific issue but on several grammatical phenomena (morphophonology, syntax, semantics) - this imitates real life situations where learners come across more linguistic phenomena at the same time when using everyday language.

The tasks in the different subjects are prepared on proficiency levels $\mathrm{A} 1-\mathrm{B} 1 / \mathrm{B} 2$, so that each pupil can join the teaching-learning process on his/her own level of language knowledge. The different language levels are clearly indicated for the children. The main character of the StepTogether tools is Kócos, the mischief-maker Hungarian shepherd dog (puli), who often mixes up words, numbers, and things. The puli dog is a lovely Hungarian symbol; he guides students in the winding paths of Hungarian language and makes the graphics of the learning tools coherent. Language levels are indicated by bone icons (the higher the level, the more the bones): pupils are playfully motivated to feed the hungry doggy by choosing tasks with as many bones as possible. 
As grammar is organised in a spiral manner, it may seem that in our teaching tools the emphasis is on vocabulary, not on grammar. We agree with Laakso (2015: 184) in that the main obstacle in learning a language is not grammar - since it is a structured system - but vocabulary. This is especially true for school subjects (such as biology, history, mathematics etc.), because their grammar is the same but their terminology differs considerably. We mapped the technical terminology of the lexical matrix keeping in mind the relevant parts of NCC and the framework curricula, and we processed the course books, workbooks and teaching tools currently used in teaching each subject. This method was chosen because educational institutions do not always use the same set of books for teaching the same subject.

We applied a set of criteria to assign the lexical elements of the subject topics to different levels:

a) fit with the CEFR and HSL Threshold Level,

b) morphological structure,

c) semantic complexity,

d) term usage in different levels of grammatical and syntactic phenomena,

e) the importance of the term in the (subject) topic.

The combination of these criteria determine the difficulty of the tasks irrespective of the pupil's age. However, the subject contents are agerelated by way of their positioning in the NCC. For the reason highlighted in point e), a lexical element for lower classes (if it is not core part of the subject content) may be graded up to a higher language proficiency level while the same lexical element can be found on a lower level in upper classes, because it is part of the basic vocabulary for the subject topic that enables communication.

At the level A1, the basic keywords of the topic and words with a simple structure (no compounds, no more than one derivational affix) are collected. A1 lexical items occur with colligation patterns classified to level A1 in grammar, and they are used in everyday language as well 
(e.g. szög means 'nail' in everyday language, but in geometry, it is the technical term 'angle').

At the level A2, words can be found that assist deeper understanding of the topic. As for their structure, they can be simple words, compounds or derivatives. A2 lexical items occur with colligation patterns classified to level A2 in grammar. A2 words usually occur in everyday language as well, but their terminological meanings often differ from their everyday meaning (e.g. csúcsszög 'opposite angle' and szögcsúcs 'angle tip, vertex' are compounds consisting of szög 'angle' and csúcs 'peak', but their terminological meaning cannot simply be derived from their parts).

At the level B1, the words are necessary for a deep level of understanding and the accurate acquisition of the topic. Many of them represent abstract concepts that are not easy to explain and understand (e.g. háromszög 'triangle'). B1 lexical items can be very diverse in their structure (e.g. egyenesszög 'straight angle'). Most of these terms are not used in everyday language.

At the level B2, there are complex compound words or word structures (e.g. szögpár 'angle pair', szöges drót 'barbed wire'). B2 lexical items occur with colligation patterns of the level B2 in grammar. Structurally they are word structures with an independent meaning (e.g. szöges cipö 'studded shoes'), which children may identify relatively easily from everyday life, that is, there is no need for a kind of abstraction that would require its inclusion in a higher category.

The category "other" includes words which are very complicated in terms of grammar or structure and require a high level of abstraction concerning their semantic features (e.g. konvex szög 'convex angle').

These levels of terminology are elaborated in the lexical matrices, the vocabulary flashcards and the tasks.

The contents are designed to facilitate integration. Our tools help the environmental, social and cultural integration of migrant children. In a narrow sense, this can be understood as integration into the immediate environment of the child, into the community of the classroom. The various forms of integration are facilitated by a so-called direct 
relationship-building task: the child is instructed to ask for the help of a classmate to complete a task. An example of such a task is given in Figure 3: "What is this boy wearing? Ask your neighbour, s/he will name an item of clothing (for instance, red shoes), you will draw them. Then you name a garment, and your neighbour will draw it. Write down in what kind of clothes you dressed him!"

29. Társasjáték. Mit visel ez a fiú?

öltöztesd fel a padtársaddal ezt a fiút!

Mit visel ez a fiú? - kérdezd meg a padtársadtól.

A padtársad mond egy ruhadarabot (pl. piros cipő).

Te lerajzolod. Majd te mondasz egy ruhadarabot, azt a padtársad rajzolja le.

Írd le, milyen ruhát adtatok rá!

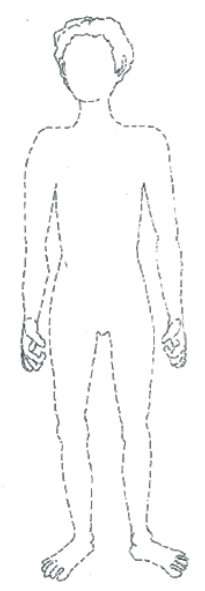

FIGURE 3. Exercise from StepTogether (Hungarian Heritage II: 43)

It is highly important that children can freely decide whether to draw clothes linked to European or another culture, since this way they can mutually transfer their cultural knowledge to their peers.

The second type of integration task is the indirect relationshipbuilding task, such as Write down the first name and surname of five of your classmates, which helps the child practice the grammatical features of Hungarian names and get to know his or her classmates better.

Group work is another type of integration task, which requires the collective work of children with different mother tongues and differing levels of language skills. Each member of the group has to participate in completing the task, while the groups may organise themselves, assign tasks and roles (team captain, material and time manager, reporter etc.) independently or with the teacher's support. Group work can be conducted in class or the teacher can schedule a deadline for completion 
(e.g. one or two weeks to finish the task collectively). This type of tasks is clearly inspired and influenced by CIP Equity Pedagogy. For the sake of integration in the wider environment as well, we designed tasks which provide information about Hungary and the European Union (Figure 4). In this example task students are asked to write down the names of the different ethnic groups of the Carpathian Basin, adding the appropriate plural suffix (többes szám jele) to the word stem (szótö).

\section{Kik élnek a Kárpát-medencében?}

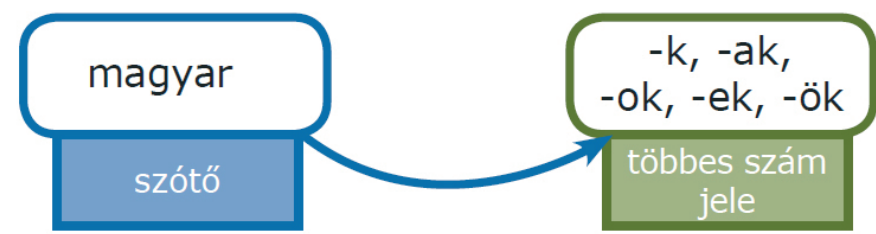

népnevek: magyar, szlovák, ukrán, román, szerb, horvát, szlovén, osztrák

A Kárpát-medencében élnek

FigURE 4. Exercise from StepTogether (Hungarian Heritage II: 34)

The third type of integration tasks is supplemented by tasks facilitating native proficiency, such as looking up words in the dictionary, which means that the same content and lexeme is written down in Hungarian, a lingua franca of their choice and their mother tongue. Teachers tend to worry most about not being able to check whether the words in the children's native language are correct, so it is quite difficult to get the task across to them and make them see the usefulness of this kind of task.

The final type of integration tasks requires the children to introduce their own culture to their classmates, and which we hope to increase acceptance and inclusion on behalf of predominantly Hungarian speaking groups e.g. Introduce a famous figure of your religion. Ask help from your parents.

All in all, NyIT involves both the methodological concerns of CLIL and the aim of the StepTogether program: it is an opening up from 
language teaching to a special set of teaching tools and knowledge, from teaching content to the process of teaching and learning the language.

\section{In practice}

In this part, we will show a few example units and tasks designed for different levels of grammatical structures: phonetical, morphological, lexical, sentence-based and textological levels.

\subsection{Phonological units}

Exercises based on phonological units can be used with any subject topic (e.g. history, mathematics, biology, Hungarian grammar), because vowels and consonants can be found in every word at any level. The goal is to recognize the connection between sounds and letters. At higher levels, L2 Hungarian students have to recognize morpho-phonological structures, sound changes in word stems and suffixes.

\section{Hol hallod a $\mathbf{j}$ hangot?}

A j és ly betúket azonosan ejtjük: [j]. Csak a hagyomány miatt írunk bizonyos szavakban ly betűt.
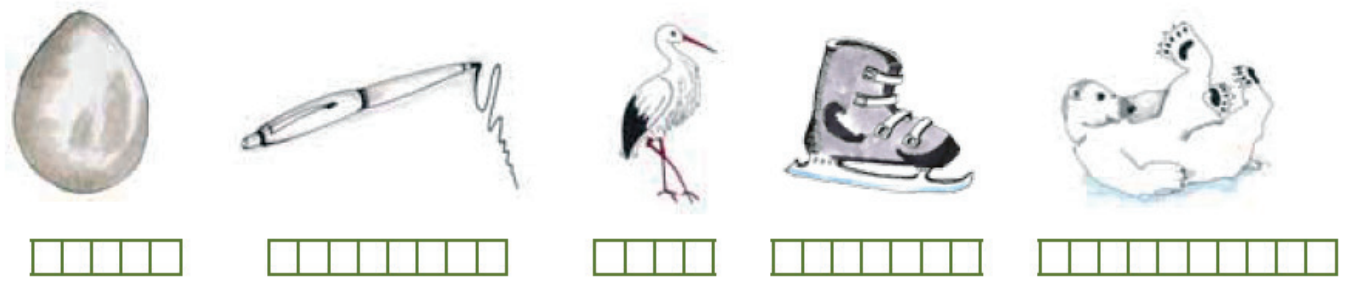

FIGURE 5. Phonological task from StepTogether (Hungarian grammar 4: 9)

The example task (Figure 5) focuses on recognizing defined phonemes. On level A1, students should be able to determine the place of the phoneme $/ j /$ within the lexical item. In addition, there is a short text informing students about the fact that the phoneme $/ j /$ has two different orthographic representations, $j$ and $l y$. 


\subsection{Morphological units}

The tasks connected to morphological units are illustrated with the following science tasks, but they can be linked to any subject content for practicing grammar.

\section{Melyik toldalék illik a szóhoz? Írd le a szavakat!}

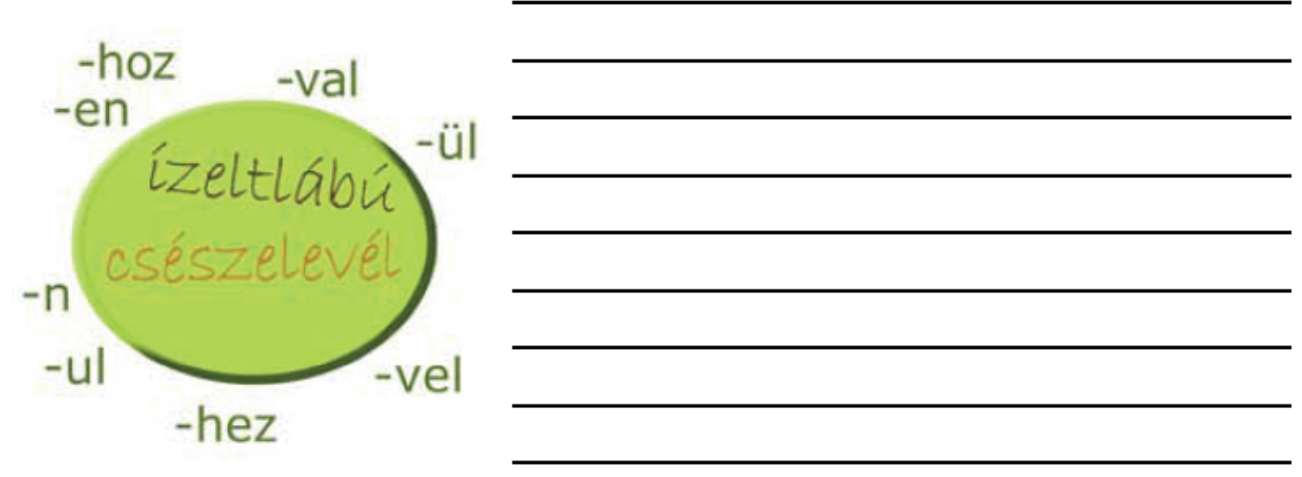

FIGURE 6. Morphological task from StepTogether (Nature Science 3: 28)

The example in Figure 6 gives children an opportunity to practice different types of suffixes and their variants (case suffixes: allative -hoz/-hez, instrumental -val/-vel, superessive -n/-en, essive -ul/-ül) together with different word stems. Besides, the lexical units and word stems used in the tasks (here: ízeltlábú 'arthropod', csészelevél 'sepal') are also connected to the curriculum and syllabi of science, at a lexical level appropriate for the grammatical level. The goal in this type of exercises is to help students recognize the different parts (word stems and suffixes) of the words.

\subsection{Lexical units}

The goal of the tasks designed for the practicing of lexical units is to help children recognise borders between words and identify different word formats. The difficulty of each task is determined by the subject content to be processed. 


\section{Olvasd el a szöveget, majd másold le!}

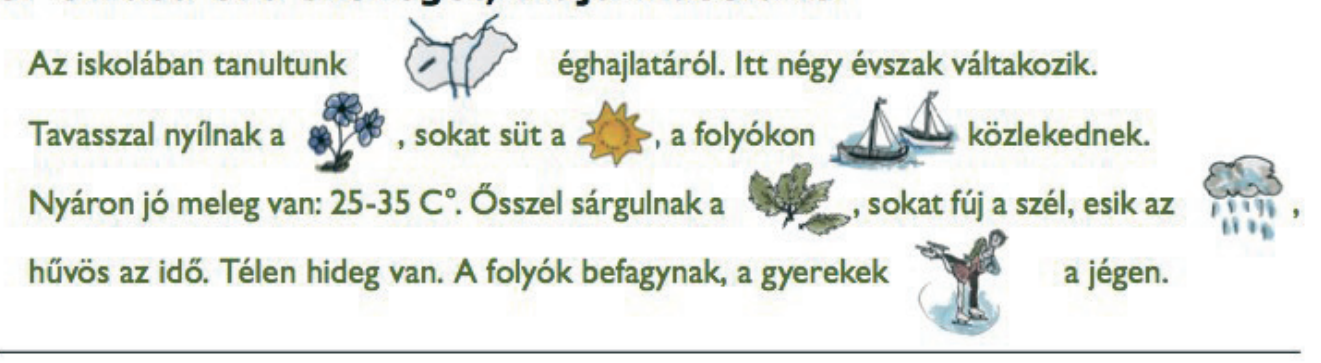

FIGURE 7. Lexical task from StepTogether (Professions and Trades II: 18)

The example in Figure 7 is an A1 task in which the pupils are instructed to complete the text by assigning a lexical equivalent to the visual information provided, e.g. country, flower, ship or leaves. The pupils can determine the words based on the pictures and also insert them into the text, i.e., place them into context.

\subsection{Sentence- and text-based units}

The main goal of syntactic and textual tasks is to recognize sentence structures and practice them, from simple to more complex ones. At lower levels - mainly A1 and A2 - the tasks are related to recognizing and building simple sentences, while at higher levels (B1-B2) complex sentences appear and pupils are required to produce shorter/longer texts.

The task in Figure 8 represents a sentence building task at the level B2. The students are instructed to briefly compare behaviour patterns in Hungarian culture and their own culture, on the basis of a certain type of relationship. As the instruction tells, Write a short comparative text. What are the common etiquette rules in your culture between men and women, young and old people, superior and subordinate employees? Find customs in other parts of the world which differ from those in Europe. 
140. Írj rövid összehasonlítást! A te kultúrádban milyen

illemszabályok vannak férfi-nő, fiatal-idős, fönök-beosztott

között?/ Keress a világban az európaitól eltérő szokásokat!

FIGURE 8. Sentence-based task from StepTogether (Labour Market Communication: 77)

As the task shows, it is not only the distinction between the meaning of the lexical units férfi 'man' - nö 'woman' or fönök 'boss' - beosztott 'subordinate employee' that appears here but the aspect of cultural differences as well.

\section{Conclusion}

The developers of the programme and the teachers using the tools created in the projects have their own distinctive conclusions. For the authors, the fact that in the past five years more and more schools, teachers and parents joined and tried out the programme or use one of its components is definitely positive feedback. This indicates that the link between teaching HSL and various subjects needs to be strengthened so that migrant pupils can more effectively participate in the Hungarian education system, in which an academic proficiency level in the Hungarian language is expected in the teaching of all subjects. It is important that our method is not subject-specific: the developers adapted it from general education subjects (e.g. mathematics and biology) to specific subjects (such as vocational guidance), and it also lends itself to further adaptations. The trial teaching sessions shed light on the fact that the usability of our teaching tools is not limited to a certain school type or method of classroom teaching - the tools were used by both primary and secondary schools; in 'general' classes, differentiated education and 
HSL classes; as well as for remedial classes, grammar clubs mentoring activities and tutoring in small groups. The teachers claimed that the teaching tools generated a significant rise in vocabulary in the short run, while in the long run the tools improved the grammatical knowledge of the pupils/students. For the children, the dog Kócos is a lovable character, and by experiencing success in their own language level, their motivation for learning increased. The vocabulary flashcards, with their use of drawings and pictures, may help to build a bridge in basic communication between teachers and parents without the use of a lingua franca.

\section{References}

Baker, Colin 2011. Foundation of Bilingual Education and Bilingualism. 5th Ed. Clevedon: Multilingual Matters.

Bunch, George C., Rachel A. Lotan, Guadalupe Valdes, Elizabeth Cohen 2005. Keeping content at the heart of "Content-Based Instruction": Access and support for transitional English learners. - D. Kaufman, J. Crandall (Eds.), Content-Based Language Instruction In Primary and Secondary School Settings. TESOL Press.

Cohen, Elizabeth G. 1991. Teaching in multiculturally heterogeneous classrooms. Findings from a model program. - McGill Journal on Education 26, 7-23.

Cohen, Elizabeth G., Rachel A. Lotan (Eds.) 1997. Working for Equity in Heterogeneous Classrooms: Sociological Theory in Practice. New York: Teachers College Press.

Cohen, Elizabeth G., Rachel A. Lotan 2004. Equity in heterogeneous classrooms. James A. Banks, Cherry A. McGee Banks (Eds.), Handbook for Multicultural Education. 2nd Ed. San Francisco: Jossey-Bass, 736-750.

Coyle, Do, Philip Hood, Philip Marsh 2010. CLIL Content and Language Integrated Learning. Cambridge: CUP.

Gothard, Bill, Phil Mignot, Marcus Offer, Melvyn Ruff 2001. Careers Guidance in Context. London: Sage Publications.

Gödri, Irén 2013. Migráció nemzeti / nyelvi határokon belül. Bevándorlók és új állampolgárok a szomszédos országokból - változó trendek. - Magyar Tudomány 3, 263-274.

European Commission/EACEA/Eurydice 2013. Education and Training in Europe 2020: Responses from the EU Member States. Eurydice Report 6. Brussels: Eurydice. 
Honko, Mari 2014. Languages of young school-age children representing the second generation: The vitality and proficiency of first and second languages in immigrant families in Finland. - Johanna Laakso (Ed.), Dangers and Developments: On Language Diversity in a Changing World. Studies in European Language Diversity 34. ELDIA Publications, 107-124.

Kecskés, Judit, Mária Kovács 2015. The metamorphosis of identity of migrant students participating in an impovement of the Hungarian language competences program. - František Alabán (Ed.), Metamorfóza identity v literatúre a jazyku II. Banská Bystrica: Vydavatel'stvo Univerzity Mateja Bela, $106-116$.

Kiadványfüzet 2014-2015. Kiadványfüzet. http://www.bmbah.hu/jomla/index. php?option=com_k2\&view=item\&layout=item\&id=177\&Itemid=1232\&l ang=hu (10.2.2016).

Laakso, Johanna 2015. The Finno-Ugric foundations of language teaching. Lähivõrdlusi. Lähivertailuja 25, 172-190. http://dx.doi.org/10.5128/ LV25.07

Nagy, Emese K. 2012. Több mint csoportmunka. Munka heterogén tanulói csoportban. Budapest: Nemzeti Tankönyvkiadó.

Nat 2012. Nemzeti alaptanterv (National Core Curriculum). - Magyar Közlöny 66, 10635-10847. http://ofi.hu/sites/default/files/attachments/mk_nat_20121. pdf (10.2.2016).

Réger, Zita 1995. Cigány gyerekek nyelvi problémái és iskolai esélyei. - Iskolakultúra 24, 102-105.

Réger, Zita 2002. Utak a nyelvhez. Nyelvi szocializáció - nyelvi hátrány. Második kiadás. Budapest: Soros Alapítvány, MTA Nyelvtudományi Intézet.

Rostás, Édua 2015. Kommunikáció, integráció, innováció. Esettanulmány a magyar és kínai közoktatás interkulturális aspektusairól. - Folmeg Márta, Jóri Anita (Eds.), Világ és nyelv szenvedéllyel. Köszöntő kötet Gecső Tamás 60. születésnapjára. Budapest: Tinta Könyvkiadó, 91-99.

Schmidt, Ildikó 2014. A magyar közoktatásba belépő migráns tanulók komplex nyelvi szintfelmérése. - THL2 (Journal of Teaching Hungarian as a 2nd Language and Hungarian Culture) 1, 22-33.

Tschibozo, Guy 2013. Leveraging diversity to promote successful transition from education to work. - Guy Tschibozo (Ed.), Cultural and Social Diversity and the Transition from Education to Work. London: Springer, 3-20.

Tóth, Judit 2013. Migrációs jogi környezet Magyarországon. - Magyar Tudomány $3,244-250$. 
Trickett, Edison J., Curtis J. Jones 2007. Adolescence culture brokering and family functioning: A study of families from Vietnam. - Cultural Diversity and Ethnic Minority Psychology 13 (2), 143-150. http://dx.doi. org/10.1037/1099-9809.13.2.143

Várhalmi, Zoltán 2013. A magyar nyelvtudás integrációs vonatkozásai. - Kováts András (Ed.), Bevándorlás és integráció. Magyarországi adatok, európai indikátorok. Budapest: MTA Kisebbségkutató Intézet.

Wetzel, Tamás 2011. A bevándorlás kérdése Magyarországon. Budapest: Publikon Kiadó.

\section{Édua Rostás}

University of Miskolc, Institute of Hungarian Linguistics and Literature

Miskolc-Egyetemváros B/2

3515 Miskolc, Hungary

edua.rostas@uni-miskolc.hu

\section{Kecskés Judit}

University of Miskolc, Institute of Hungarian Linguistics and Literature Miskolc-Egyetemváros B/2

3515 Miskolc, Hungary

kecskes.judit@uni-miskolc.hu 


\title{
StepTogether: mahdollinen ratkaisu unkarin opettamiseksi toisena kielenä maahanmuuttajalapsille
}

\author{
ÉDUA ROSTÁS, JUDIT KECSKÉS \\ Miskolcin yliopisto
}

Artikkeli esittelee StepTogether-ohjelmaa, jonka päämääränä on kehittää maahanmuuttajalasten unkarin kielen taitoa ja tätä kautta torjua koulunkäynnin keskeyttämistä sekä helpottaa heidän siirtymistään peruskoulusta keskiasteen koulutukseen. Artikkelin tekijät ovat kehittäneet CLIL:n (Content Language Integrated Learning) mukaisia opetusvälineitä, ja he tarjoavat opettajille käytännön apukeinoja heikosti unkaria osaavien lasten integroimiseksi perinteiseen koulutyöhön. Ajatuksena on edistää lasten kielitaidon kehittymistä (tasolta A1 tasolle B2) samalla kun he opiskelevat matematiikasta, historiasta, biologiasta, kieliopista ja muista aineista samoja asioita kuin luokan muut oppilaat. Artikkeli käsittelee ohjelman päämääriä, eri vaiheita, metodista taustaa ja käytännön esimerkkejä.

Avainsanat: CLIL; koulun keskeyttäminen; kotouttaminen; maahanmuuttajalapset; Eurooppalainen viitekehys; spiraalikielioppi 